Economia e Sociedade, Campinas, Unicamp. IE.

\title{
Governança, federalismo e crise do Fundo Nacional de Desenvolvimento Científico e Tecnológico - FNDCT *
}

\author{
João Carvalho Leal ${ }^{* *}$ \\ Alexandre Coelho Teixeira ${ }^{* * *}$ \\ Geraldo Eustáquio Moreira ${ }^{* * * *, * * * *}$
}

\section{Resumo}

Este artigo analisa o federalismo na governança do FNDCT e a relação com a crise pela qual passa atualmente esse Fundo. Considera como referência os sistemas nacionais de políticas públicas em construção no Brasil, a exemplos das áreas da Saúde, Educação e Assistência Social. As informações oficiais analisadas indicam que a adoção do federalismo no arranjo político-institucional da governança do FNDCT se restringe a exigências legais de percentuais mínimos dos recursos destinados às regiões menos desenvolvidas economicamente. Essas informações admitem levantar a hipótese de que a inobservância de princípios federativos contribuiu para a fragilidade políticoinstitucional da governança do FNDCT, e consequentemente, para a gestação de uma grande crise organizacional e financeira desse Fundo. Dentre os fatores geradores dessa crise, destacam-se os desvios das finalidades originárias dos recursos atribuídas em lei, crescente instabilidade de arrecadação e perdas de fontes de receitas.

Palavras-chave: FNDCT - Fundo Nacional de Desenvolvimento Científico e Tecnológico; Federalismo; Governança; Política pública.

\section{Abstract \\ Governance, federalism and the crisis of the National Fund for Scientific and Technological Development (FNDCT)}

This article analyzes the federalism in the governance of the FNDCT and how it relates to the crisis the fund is currently facing. It considers, as a reference, the national systems of public policies under construction in Brazil, for example, in the areas of Health, Education and Social Assistance. The official information analyzed has indicated that the adoption of federalism by the FNDCT's governance is restricted to legal requirements of minimum percentages of resources allocated to economically less developed regions. This information allows us to raise the hypothesis that failure to observe federative principles contributed to the political and institutional fragility of the FNDCT's governance and, consequently, to the gestation of a major organizational and financial crisis faced by the FNDCT. Among the factors responsible for this crisis are the deviations from the original purposes of the resources allocated by law, increasing instability of fundraising and loss of revenue sources.

Keywords: FNDCT, Federalism, Governance, Public policy.

JEL H77, O31, O32, O38.

\footnotetext{
${ }^{*}$ Artigo recebido em 13 de dezembro de 2017 e aprovado em 18 de setembro de 2019.

${ }^{* *}$ Secretaria de Economia do Distrito Federal, Brasília, DF, Brasil. E-mail: carvalholeal@gmail.com.

*** Analista em Ciência e Tecnologia do Ministério da Ciência, Tecnologia e Inovação, Brasília, DF, Brasil. E-mail: alexandre.teixeira@mctic.gov.br.

**** Professor Adjunto da Universidade de Brasília (UnB), Brasília, DF, Brasil. E-mail: geust @unb.br.

****** Pesquisador dos Programas de Pós-Graduação Stricto Sensu em Gestão Pública (Mestrado Profissional) e Educação (Mestrado e Doutorado), ambos da UnB, Brasília, DF, Brasil.
} 


\section{Introdução}

Na administração pública, o termo "governança" pode ser utilizado para se referir ao modo como a autoridade é exercida na gestão das políticas públicas de forma compartilhada entre diferentes agentes (públicos e privados), mediante representações de setores e entes federativos. Assim, além do modus operandi da gestão, "governança" abrange os arranjos político-institucionais das relações de poder dentro e entre cada sistema de política pública, envolvendo a participação de diferentes agentes no poder decisório. Nesses arranjos, as relações envolvem interesses de partidos políticos, entidades de classe, associações e grupos sociais informais de diversos tipos (Santos, 1997, 2001).

Nesse sentido, o artigo motiva-se pela constatação de que a consideração do federalismo na governança do Fundo Nacional de Desenvolvimento Científico e Tecnológico (FNDCT) se restringe à mera destinação regional de recursos para incentivar as atividades de Ciência, Tecnologia e Inovação (CT\&I), em detrimento da observância dos princípios básicos de um estado federativo - seja do lado das decisões sobre arrecadação de recursos (fontes de receita, orçamento e execução fiscal), seja do lado da destinação de recursos. Em algum momento no futuro próximo, isso será contornado, conforme determinações da Emenda Constitucional - EC n. 85, de 26/02/2015 - que estabelece, dentre outras determinações, a previsão legal para se efetivar a colaboração dos entes federativos na construção do Sistema Nacional de CT\&I.

O estudo dos aspectos federativos da governança da Política Nacional de CT\&I, com o exemplo do FNDCT, é importante para entender a crise atual, de primazia organizacional (e não financeira, como comumente se enfatiza), por qual passa esse fundo, e orientar futuras revisões político-institucionais a partir das determinações da EC n. 85/2015. Considera como referência institucional sistemas nacionais de políticas públicas em construção no Brasil com a observância dos princípios federativos, como os das políticas de Saúde, Educação e Assistência Social. O artigo parte da premissa da abordagem clássica do federalismo de que a observância de princípios como o da participação e autonomia política dos entes federados, assim como das representações setoriais de CT\&I, fortalece o arranjo federativo do Estado e, ao mesmo tempo, possibilita a contenção de fatores geradores de crise.

Assim, o presente artigo introduz no debate a hipótese de que a desconsideração da perspectiva do federalismo (ou seja, a inobservância de princípios federativos) pela governança do FNDCT contribuiu para a fragilidade político-institucional de sua governança, e consequentemente, para a gestação de uma crise organizacional e financeira sem precedentes: do lado da arrecadação de recursos (definição de fontes, orçamento e execução fiscal), a instabilidade de arrecadação e perdas de fontes de receitas; e do lado da destinação de recursos, desvios de finalidades. Dentre os fatores geradores dessa crise, o artigo destaca do lado da arrecadação: a prática de substituição de fontes; a aprovação das dotações nas Leis Orçamentárias Anuais com valores menores do que as efetivas arrecadações dos recursos; contingenciamentos e perda de fontes de receitas; e do lado da destinação, o avanço da discricionariedade na execução dos recursos do FNDCT via ações transversais. 
Diferentemente do que acontece nas políticas públicas de Saúde, Educação e Assistência Social, vigora atualmente na governança do FNDCT a completa ausência de participação dos entes subnacionais e o desaparecimento das representações setoriais das atividades de CT\&I, contrariamente ao que se espera desde a $2^{\text {a }}$ Conferência Nacional de CT\&I de 2002: participação conjunta dos entes subnacionais com representações dos setores produtivos nas decisões de arrecadação e destinação estável de recursos; e, definição de regras, objetivos, diretrizes para implementação de programas setoriais de C\&T.

Isso posto, o artigo: i) descreve os aspectos gerais dos esforços do Estado Brasileiro para considerar a perspectiva do federalismo na Política Nacional de CT\&I, com ênfase no arranjo político-institucional da governança do FNDCT; ii) analisa como se dá a observância ou inobservância dos princípios federativos na governança do FNDCT e como se configurou o processo de fragilização de arranjo político-institucional; e, em seguida, iii) analisa a crise atual do FNDCT como consequência da fragilização político-institucional da sua governança, e tece algumas considerações sobre o seu futuro.

\section{Federalismo nas políticas públicas: os esforços do Estado brasileiro}

Para descrever os esforços do Estado Brasileiro para considerar a perspectiva do federalismo na Política Nacional de CT\&I, com ênfase no FNDCT, esta seção parte de uma revisão bibliográfica sobre os aspectos conceituais e gerais da relação entre federalismo e políticas públicas.

\subsection{A perspectiva do federalismo}

Partindo dos clássicos do federalismo e dos modelos conceituais ou "versões" de federalismo na Europa e nas Américas, Fiori (1995) foi pioneiro no Brasil na identificação das características que devem existir no federalismo dos Estados contemporâneos para que sejam mais estáveis em termos de arranjos político-institucionais. Dentre essas características, está a "equidade" entre as unidades federadas. Como princípio, essa característica permite "legitimar solidariamente a convivência federativa", mas pressupõe a existência de instrumentos e mecanismos comuns de políticas públicas capazes de compensar, de maneira imediata, desequilíbrios agudos e inesperados, promovendo uma progressiva diminuição das desigualdades estruturais entre as regiões. Fiori (1995) destaca a importância das negociações entre unidades federadas que passam cada vez mais pela defesa de interesses econômicos e pela necessidade de impedir o aumento das desigualdades econômicas inter-regionais: "se essas negociações não forem construídas sobre estruturas econômicas cujo dinamismo aponte para a integração cada vez maior dos espaços federados, volta-se ao problema das pressões desintegradoras que podem esfacelar o Estado federado" (Fiori, 1995, p. 25).

Ao definir a organização federal dos Estados, Burdeau (1967) destaca a autonomia, participação e cooperação como princípios básicos. A autonomia foi tratada como o princípio da autodeterminação garantida pela Constituição às partes federadas; a participação, como 
responsabilidade de cada subsistema federativo, especialmente na política econômica, o que remete diretamente ao princípio da cooperação entre entes federativos; e, na cooperação, os autores destacam não só a horizontal, aquela pactuada entre as unidades federadas ou subnacionais, mas também a cooperação vertical, praticada de baixo para cima para atender os interesses da União naquilo que diz respeito à satisfação das demandas sociais e ao equilíbrio macroeconômico dos países (Burdeau, 1967).

A literatura brasileira pouco enfatiza os princípios da organização de um Estado federativo no desenvolvimento dos arranjos político-institucional das políticas públicas (Souza, 2005); Amaral Filho, 2014). No Brasil, há relativo consenso de que diante dos conflitos federativos na esfera macroeconômica (fiscal e financeira), o debate inclina-se historicamente para o dilema da centralização versus descentralização do poder sobre a tributação e a destinação de recursos (Lopreato, 1997, 2000, 2002; (Oliveira; Biasoto Júnior, 2015 e Arretche, 2005). Não obstante a inclinação do debate, a perspectiva do federalismo tem sido considerada na formulação de alguns sistemas de políticas públicas.

\subsection{O federalismo nas políticas públicas brasileiras}

O contexto político e econômico do Brasil no pós-Constituição Federal de 1988 doravante, $\mathrm{CF} / 88$ - sinalizou para a institucionalização do poder político mais descentralizado, com maior autonomia dos entes subnacionais, mas ao mesmo tempo, com a cooperação nas políticas públicas, conforme a determinação expressa do parágrafo único do artigo 23 da própria $\mathrm{CF} / 88$. Entretanto, quase trinta anos depois, o intento federalista na formulação e gestão compartilhada da maioria das políticas públicas brasileiras continua frágil.

São raríssimas as áreas ou as políticas públicas em que se desenvolveram arranjos político-institucionais com participação conjunta e em regime de colaboração entre os entes federados. Basicamente, a literatura cita três áreas ou sistemas em que esses arranjos se desenvolveram melhor: a Política Nacional de Saúde, a Política Nacional de Educação e a Política Nacional de Assistência Social (Costa; Cunha; Araújo, 2010; Dourado, 2013; Ribeiro; Maciel, 2014 e Rizzotto; Campos, 2016).

Para a Política Nacional de Saúde, a CF/88 estabeleceu como principal diretriz que as ações e serviços públicos de saúde integram uma rede regionalizada, hierarquizada, descentralizada e com direção única em cada esfera de governo. Também estabeleceu percentuais mínimos da receita corrente líquida que cada ente - União, Estados, Distrito Federal e os Municípios - deve aplicar em ações e serviços públicos de saúde. Esses dispositivos constitucionais foram regulamentados pela Lei n. 8.080 de 19/09/1990, que criou no âmbito da política: o Conselho Nacional de Secretários de Saúde (Conass), entidade representativa dos entes estaduais, e o Conselho Nacional de Secretarias Municipais de Saúde (Conasems), entidade representativa dos entes municipais. O Conselho Nacional de Saúde (CNS) já havia sido criado pela Lei n. 378 de 13/01/1937, entretanto, a partir da CF/88, as competências do CNS foram redefinidas para coordenar a Política Nacional de Saúde em regime de colaboração entre os entes federados (Franzese; Abrucio, 2009; (Arretche, 2004). 
Em relação à Política Nacional de Educação, a CF/88 estabeleceu que a União, os Estados, o Distrito Federal e os Municípios organizassem em regime de colaboração seus sistemas de ensino. Além disso, a CF/88 estabeleceu as principais competências de cada ente federativo. À União, coube organizar o sistema federal de ensino, financiar as instituições de ensino públicas federais e exercer, em matéria educacional, função redistributiva e supletiva, de forma a garantir equalização de oportunidades educacionais e padrão mínimo de qualidade do ensino mediante assistência técnica e financeira aos Estados, ao Distrito Federal e aos Municípios. Aos Estados e ao Distrito Federal, coube a prestação prioritária do ensino fundamental e médio. E, aos Municípios, coube a prestação prioritária do ensino fundamental e da educação infantil. A própria $\mathrm{CF} / 88$ estabeleceu os percentuais mínimos das receitas de cada ente a serem aplicadas, anualmente, na prestação da educação (Costa; Cunha; Araújo, 2010).

Quanto à Política Nacional de Assistência Social (PNAS), a CF/88 determinou como diretriz a descentralização político-administrativa e estabeleceu como competência: da União, a coordenação da política e a aprovação de normas gerais; e dos estados e dos municípios também a coordenação da política e a execução dos respectivos programas. Esses dispositivos da CF/88 foram regulamentados pela Lei n. 8.742 de 07/12/1993, que criou o Conselho Nacional de Assistência Social (CNAS), com representação dos e Estados e dos Municípios, e determinou a criação dos Conselhos Municipais de Assistência Social (CMAS), mediante lei municipal. Além disso, a Lei n. 8.742/1993 estabeleceu que os CMAS fossem vinculados ao Órgão Gestor de Assistência Social, com atribuição de prover a infraestrutura necessária aos seus funcionamentos, garantindo recursos materiais, humanos e financeiros. A gestão compartilhada da PNAS foi denominada de Sistema Único de Assistência Social (SUAS) pela Lei n. 12.435 de 06/07/2011 (Arretche, 2002, 2004); (Ribeiro; Maciel, 2014).

\subsection{O esforço para introduzir a perspectiva do federalismo na Política Nacional de CT\&I: o exemplo do FNDCT}

A formulação da Política Nacional de CT\&I não fugiu à regra das políticas públicas brasileiras em que não se desenvolvem arranjos político-institucionais baseados na cooperação entre os entes federativos. Ao analisar tipos ideais de federalismo, Théret (2015) destaca a importância dessa cooperação na elaboração de políticas públicas:

Um tipo ideal intraestatal y de estilo cooperativo (entre la federación y las entidades federadas) de federalismo, en el cual un senado federal poderoso representa a los estados federados de manera igualitaria (todo estado dispone de un mismo número de escaños, dos en el caso de Estados Unidos, que es el arquetipo en la materia) y les permite participar en la elaboración de las políticas públicas federales (Théret 2015, p. 106, grifos nossos).

A CF/88, antes da EC n. 85/2015, trazia um capítulo para o Estado tratar da ciência e tecnologia. Entretanto, não estabelecia qualquer determinação ou diretriz para que a Política Nacional de CT\&I fosse instituída em regime de colaboração entre os entes federados. 
Ciente dessa desconsideração da perspectiva do federalismo, a $2^{\mathrm{a}}$ Conferência Nacional de CT\&I defendia a participação dos estados na gestão da Política Nacional de CT\&I:

Estender as oportunidades e os benefícios da CT\&I aos diversos espaços brasileiros e corrigir as desigualdades historicamente acumuladas na construção do aparato científico e tecnológico inspiraram a construção de uma agenda regional com desdobramentos nas diversas iniciativas do MCT. Tal agenda vem sendo progressivamente ampliada para responder aos desafios nesta área. Um novo modelo de gestão compartilhada com os estados brasileiros foi implantado para seleção e identificação de prioridades e empreendimentos conjuntos. Os esforços cooperativos têm evoluído, o que se confirma pelo crescente interesse dos estados - especialmente daqueles com histórico de realizações científicas e tecnológicas menos pronunciado - em participar ativamente das distintas linhas de ação regional adotadas (Brasil, 2002, p. 44, grifos nossos).

Ao descrever as reformas realizadas entre 1999 e 2002 na Política Nacional de CT\&I, Pacheco (2005) explica as motivações refletidas pela $2^{a}$ Conferência Nacional de CT\&I para a participação dos entes federativos como atores relevantes dessa política, destacando a "visão" que exige articulação e compartilhamento de responsabilidades entre os entes federados, representações setoriais da academia e empresarial e dos órgãos públicos setoriais:

Los estados de la Federación y progresivamente también los municipios - motivados por el esfuerzo realizado por el MCT para incentivar las asociaciones locales y rehabilitar los Foros de Secretarios Estaduales y los Foros de las Fundaciones de Apoyo comenzaron a exigir una participación más activa en la política nacional, en la perspectiva de una mayor descentralización. Esta visión pretende instaurar un sistema de separación de las responsabilidades, al igual como existe en otras políticas públicas brasileñas, como en las áreas de educación y salud, con el traspaso automático de los recursos de la Unión a los estados y municipios. En este sentido, se argumenta que las dimensiones territoriales de Brasil y su diversidad socioeconómica recomiendan políticas cada vez más descentralizadas, con menores costos operacionales y mayor eficacia, ya que son implementadas por instituciones públicas más próximas de las respectivas clientelas, con posibilidades de comparar y evaluar mejor la demanda de recursos. Finalmente, en virtud de los grandes desequilibrios socioeconómicos existentes en Brasil, esta descentralización sería imperativa, más aún en el momento en que el conocimiento pasa a ser una variable crítica del desarrollo (Pacheco, 2005, p. 14, grifos nossos).

O relato de Pacheco (2005) sobre as reformas do Sistema Nacional de CT\&I, ocorridas entre 1999 e 2002, deixa evidente a necessidade de uma agenda regional da União para assegurar a correspondência com a obrigação de o FNDCT ("novos fundos") destinar recursos mínimos às atividades de CT\&I das regiões menos desenvolvidas, e assim, fortalecer o pacto federativo:

Incorporación de una agenda regional explícita de las acciones del MCT, que fortalezca el pacto federativo y la articulación de los intereses locales, tanto a través de la obligatoriedad de los nuevos fondos de aplicar en las regiones Norte, Noreste y Centro- 
Oeste un mínimo de $30 \%$ de sus recursos, como por medio de la creación de una asesoría de acción regional, que articula las acciones de cada Unidad de la Federación, así como por el lanzamiento de un programa de Sistemas Locales de Innovación, que seleccionan aproximadamente cien acuerdos productivos locales, apoyados por la Unión y los Estados, como estímulo a la innovación del sector privado (Pacheco, 2005, p. 9).

Com efeito, como proposto pela $2^{\mathrm{a}}$ Conferência Nacional de CT\&I, a União foi obrigada a destinar às regiões brasileiras menos desenvolvidas percentuais mínimos dos recursos não reembolsáveis dos programas e fundos setoriais criados no âmbito do FNDCT pelas reformas de 1999 a 2002. A título de ilustração desse esforço, destacam-se no Quadro 01 as exigências legais de aplicação mínima de recursos não reembolsáveis nas regiões Norte, Nordeste e Centro-Oeste.

Quadro 1

Algumas exigências legais de repartição regional no FNDCT

\begin{tabular}{|c|c|c|}
\hline Legislações & Programas e Fundos Setoriais & Aplicação Mínima Obrigatória \\
\hline $\begin{array}{l}\text { Lei n. } 10.332 \text {, de } 19 \text { de } \\
\text { dezembro de } 2001 \text { e Lei } \\
\text { n. } 10.168 \text {, de } 29 \text { de } \\
\text { dezembro de } 2000 \text {. }\end{array}$ & $\begin{array}{l}\text { Dos setores i) aeronáutico; ii) do } \\
\text { agronegócio; iii) de biotecnologia e } \\
\text { recursos genéticos; iv) de saúde; e } \\
\text { v) de estímulo à interação } \\
\text { universidade-empresa (verde } \\
\text { amarelo). }\end{array}$ & \multirow{5}{*}{$\begin{array}{l}\text { De } 30 \% \text { dos recursos dos programas em } \\
\text { programas de fomento à capacitação } \\
\text { tecnológica e ao amparo à pesquisa } \\
\text { científica e ao desenvolvimento } \\
\text { tecnológico nas regiões Norte, Nordeste e } \\
\text { Centro-Oeste. }\end{array}$} \\
\hline $\begin{array}{l}\text { Lei n. } 9.991 \text {, de } 24 \text { de } \\
\text { julho de } 2000 .\end{array}$ & $\begin{array}{l}\text { Programa do setor de energia (CT- } \\
\text { Energia). }\end{array}$ & \\
\hline $\begin{array}{l}\text { Lei n. } 9.993 \text {, de } 24 \text { de } \\
\text { julho de } 2000 .\end{array}$ & $\begin{array}{l}\text { Programas dos setores hídrico e } \\
\text { mineral. }\end{array}$ & \\
\hline $\begin{array}{l}\text { Lei n. } 10.197 \text {, de } 14 \text { de } \\
\text { fevereiro de } 2001 .\end{array}$ & Programas de infraestruturas. & \\
\hline $\begin{array}{l}\text { Lei n. } 9.992 \text {, de } 24 \text { de } \\
\text { julho de } 2000 .\end{array}$ & $\begin{array}{l}\text { Programas dos setores de } \\
\text { transporte. }\end{array}$ & \\
\hline $\begin{array}{l}\text { Lei n. } 9.478 \text {, de } 6 \text { de } \\
\text { agosto de } 1997 .\end{array}$ & Programa do setor de petróleo. & $\begin{array}{l}\text { De } 40 \% \text { dos recursos do programa em } \\
\text { fomento à capacitação e ao } \\
\text { desenvolvimento científico e tecnológico } \\
\text { das regiões Norte e Nordeste. Entretanto, } \\
\text { com a aprovação da Lei n. } 12.858 / 2013 \text {, } \\
\text { essas receitas foram transferidas para o } \\
\text { Fundo Social para serem aplicadas em } \\
\text { saúde e educação. }\end{array}$ \\
\hline
\end{tabular}

Fonte: Elaboração dos autores.

Em que pese a esse esforço, desde os idos das reformas de 1999 a 2002, a consideração da perspectiva do federalismo na Política Nacional de CT\&I não teve avanços em termos político-institucionais. O esforço ficara restrito aos instrumentos de subvenção (não 
reembolsáveis), como os do FNDCT, deixando de lado os instrumentos de incentivos fiscais a atividades de C\&T, a exemplo dos instituídos pela Lei n. 11.196 de 21/11/2005, conhecida como "Lei do Bem". Fato inexplicável quando o principal instrumento de incentivo da Política Nacional de CT\&I, as "contrapartidas dos incentivos fiscais à produção do setor das tecnologias da informação e automação", previstas na Lei n. 8.248 de 23/10/1991, mostravam o quanto era importante para o equilíbrio federativo as empresas de informática e automação destinarem parte do faturamento a projetos de pesquisa e desenvolvimento localizados fora da Zona Franca de Manaus, e não apenas, mas também para regiões menos desenvolvidas - de influência da Agência de Desenvolvimento da Amazônia e da Agência de Desenvolvimento do Nordeste -, permitindo a diversificação e a distribuição geográfica da indústria de informática e automação pelo território nacional.

O Conselho Nacional de Ciência e Tecnologia - CNC\&T, regulamentado pela Lei n. 9.257 de 09/01/1996, foi criado como órgão articulador da política, inclusive dos poderes estaduais e locais. A $2^{\text {a }}$ Conferência Nacional de CT\&I já recomendava:

\begin{abstract}
Nessa direção, será necessário, entre outras medidas, rever o papel do Conselho Nacional de Ciência e Tecnologia com vistas a fortalecer a coordenação do Sistema, e consolidar os novos mecanismos de gestão compartilhada de estratégia e recursos financeiros, sistematizada a partir da introdução dos Fundos Setoriais. (....) Neste sentido, é fundamental consolidar a cultura de parcerias entre instituições dos poderes executivos federal, estaduais e locais, com instituições do terceiro setor envolvidas em atividades de CT\&I e, em particular, com a comunidade científica representadas pela Sociedade Brasileira para o Progresso da Ciência (SBPC) e a Academia Brasileira de Ciências (ABC) e as sociedades científicas e profissionais em geral; estimular a participação de múltiplos atores institucionais; desenvolver novos mecanismos de gestão participativa, como os Fóruns dos Secretários Estaduais de Ciência e Tecnologia e das Fundações Estaduais de Amparo à Pesquisa; criar novas formas de gestão dos recursos com a participação de atores sociais e políticos relevantes; integrar a política de CT\&I com as diversas políticas econômicas setoriais - agrícola, industrial, de comércio exterior etc. - e com as políticas macroeconômicas, de modo a permitir a criação de um ambiente favorável à inovação (BRASIL, 2002, p. 64-65, grifos nossos).
\end{abstract}

Ocorre que, à margem da organização político-institucional da Política Nacional de CT\&I do Poder Executivo Federal, inclusive do Conselho Nacional de CT\&I, os Fóruns dos Secretários Estaduais de Ciência e Tecnologia e das Fundações Estaduais de Amparo à Pesquisa esforçaram-se para suprir a lacuna de participação dos entes subnacionais, com a criação, em 2006, do Conselho Nacional das Fundações Estaduais de Amparo à Pesquisa (Confap) e, em 2005, do Conselho Nacional de Secretários para Assuntos de Ciência, Tecnologia e Inovação (Consecti).

Entretanto, todas essas iniciativas foram incipientes para a perspectiva do federalismo ser considerada no arranjo político-institucional da governança da Política Nacional de C\&T, em especial, do FNDCT; e assim ser garantida a diversidade da representação dos interesses políticos pelos incentivos públicos às atividades de CT\&I. Dessa forma, as exigências legais 
de repartição regional de recursos acabaram desacompanhadas da participação dos maiores interessados, os entes subnacionais, culminando numa fragilização da governança do FNDCT, como atestado nas próximas seções.

\section{Os princípios do federalismo e a fragilização da governança do FNDCT}

Para o propósito de saber o quão insipiente tem sido a consideração da perspectiva do federalismo no arranjo político-institucional da governança do FNDCT, examina-se, mediante pesquisa documental, a observância (ou a inobservância) dos princípios do federalismo, inspirando-se em Burdeau (1967), Fiori (1995), Souza (2005), Arretche (2012; 2010) e Amaral Filho (2014).

Para Burdeau (1967), a autonomia é o princípio que provê a autodeterminação relativa de cada ente federado, assegurada pela repartição pactuada de recursos entre os entes. Sobre o princípio da participação, Burdeau (1967) considera a prerrogativa de cada ente subnacional de participar nas políticas públicas, especificamente nas decisões que afetam os respectivos entes subnacionais. Para Burdeau (1967), o princípio da participação está diretamente associado ao princípio da cooperação entre os entes federados, sobretudo se existirem altos graus de assimetria econômica no sistema federado. Em Amaral Filho (2014) e (Souza, 2005), a adoção desse princípio deveria evoluir até atingir cenários de ações cooperativas e convergentes, concretizadas por meio de "alianças, consórcios, parcerias em projetos comuns", etc.

\subsection{Quanto ao princípio da autonomia}

Quanto à autonomia dos entes federativos pela destinação dos recursos do FNDCT, pode-se considerar, como pré-requisito da observância desse princípio, a representatividade nos dispêndios estaduais - dos recursos não reembolsáveis do FNDCT destinados às atividades de C\&T. Atualmente, o FNDCT - como fundo de natureza contábil, congregado por 16 programas setoriais financiados por fundos correspondentes, denominados "fundos setoriais" 1 - é regulamentado de forma geral pela Lei n. 11.540 de 12/11/2007, e pelo Decreto n. 6.938 de 13/08/2009.

A origem da base de dados - composta por recursos não reembolsáveis do FNDCT destinados às atividades de C\&T e de inovação econômica (empresarial), utilizada nesta seção - é o Sistema Integrado de Administração Financeira (SIAFI) ${ }^{2}$. A extração desses dados do

(1) Destaca-se que a literatura tradicional sobre o FNDCT aborda a distribuição dos recursos que compõem o FNDCT referindo-se somente às categorias de programação orçamentária específicas, chamadas "fundos setoriais" de C\&T. Nesse artigo, recorre-se também à nomenclatura de "programas", denominações estabelecidas nas ementas das leis ou decretos para assegurar a destinação de recursos a áreas específicas, cuja gestão deve ser executada por comitês gestores. Essa relação entre programas e fundos foi adotada pelos Acórdãos n. 3440/2013 e n. 500/2015 - TCU - Plenário que afirmaram que o estabelecimento de diretrizes permite a definição de objetivos e metas a serem alcançados na aplicação dos recursos de cada categoria de programação orçamentária (fundos).

(2) Os recursos não reembolsáveis do FNDCT são executados nas seguintes categorias de programação orçamentária específica: CT-Aero (aeronáutica); CT-Agro (agronegócio); CT-Amazônia; CT-Biotec. (biotecnologia); CT-Energ. (energia 
SIAFI foi realizada pelo Ministério da Ciência, Tecnologia, Inovações e Comunicações (MCTIC) que estruturou uma matriz de recursos não reembolsáveis do FNDCT aplicados nos Estados e Regiões brasileiras, entre os anos de 2006 a 2013. Esses recursos não reembolsáveis são aqueles dos fundos setoriais destinados às atividades de Pesquisa e Desenvolvimento $(\mathrm{P} \& \mathrm{D})$ e às atividades Científicas e Técnicas Correlatas $(\mathrm{ACTC})^{3}$ que são outras atividades relacionadas ao apoio à inovação nas empresas. Nos termos do artigo 12 da Lei n. 11.540/2007, esses recursos são destinados:

a) a projetos de $\mathrm{P} \& \mathrm{D}$ e a ACTC de instituições científicas e tecnológicas (ICTs) e de cooperação entre ICTs e empresas; e,

b) a empresas (subvenção econômica para $\mathrm{P} \& \mathrm{D}$ e equalização de encargos financeiros nas operações de crédito).

Este artigo utiliza ainda a base de dados elaborada pelo MCTIC ${ }^{4}$ sobre a evolução dos dispêndios dos governos estaduais em atividades de C\&T e de inovação das empresas com ações não reembolsáveis, em regiões brasileiras entre 2006 a 2013. Esses dados foram comparados com os dispêndios do FNDCT em ações não reembolsáveis, mediante ações "verticais" e "transversais". As ações "verticais" são ações estabelecidas em leis específicas para a execução vinculada dos recursos dos programas setoriais de C\&T.

As ações "transversais" " não têm exigência de execução vinculada de recursos e foram previstas - após as leis que criaram os programas e fundos setoriais entre 1999 e 2002 - na Lei n. 11.540/2007 e não possuem exigências legais de regionalização dos seus recursos.

elétrica); CT-Espacial (setor espacial); CT-Hidro (recursos hídricos); CTInfo (tecnologia da informação); CT-Infra-estrutura; CTMineral (setor mineral); CT-Petro (petróleo e gás natural); CT-Saúde (saúde); CT-Aquaviário (transporte aquaviário e construção naval); CT-Transporte (transportes terrestres); CT-Inovar Auto (veículos automotores); CT-Verde-Amarelo-Fomento; Subvenção Econômica da Lei de Inovação e da Lei do Bem; Instrumentos (equalização da taxa de juros, investimentos em empresas inovadoras, incentivos ao investimento em C\&T e a própria subvenção); Organizações Sociais; Programa Ciência sem Fronteiras; Outras Ações do FNDCT, inclusive as ações transversais, que serão referenciadas nas seções seguintes. Convém observar que os recursos não reembolsáveis do FNDCT são quantificados a partir da subtração dos recursos reembolsáveis do FNDCT, destinados a projetos de desenvolvimento tecnológico de empresas (FPDTE), sob a forma de empréstimos à Finep, conforme inciso II do art. 12 da Lei n. 11.540/2007, cujo limite é de 25\% das dotações consignadas na LOA ao FNDCT.

(3) As Atividades de Ciência e Tecnologia - C\&T são consideradas como compostas pelas atividades de Pesquisa e Desenvolvimento (P\&D) mais as atividades Científicas e Técnicas Correlatas (ACTC).

(4) Dados disponíveis em: http://www.mct.gov.br/index.php/content/view/2068.html\#tt, Acesso em: 26 maio 2017.

(5) As ações "transversais" são ações geralmente estabelecidas mediante ato administrativo infralegal do Comitê de Coordenação Executiva do FNDCT que elege discricionariamente setores ou áreas, sem vinculação com os programas de C\&T estabelecidos em lei, para receber recursos do FNDCT. Na leitura de Nascimento e Oliveira (2013), entre os anos de 2004 e 2008 , essas ações contribuíram para o fortalecimento da infraestrutura de pesquisa científica e tecnológica e para o fomento à PD\&I em áreas estratégicas. Entretanto, esses autores destacam que as ações transversais não foram capazes de desempenhar o papel para o qual teriam sido criadas - o de dar maior organicidade, uniformidade e coordenação à governança dos fundos setoriais. Em análise para período posterior ao ano de 2008, o Tribunal de Contas da União constatou forte desvirtuamento do FNDCT na execução dessas ações transversais, o que ficou consubstanciado nos seguintes julgados: Acórdão n. 686/2005 - TCU - Plenário; Acórdão n. 3081/2008 - TCU - Plenário; TC-002.105/2012-8 que resultou no Acórdão n. 2000/2012 - TCU - Plenário; TC n. 015.995/20127 que resultou no Acórdão n. 3440/2013 - TCU - Plenário. 
Para entendimento geral, os dispêndios globais do FNDCT, entre os anos de 2006 e 2013, representaram anualmente, em média, 8,65\% do total dos dispêndios do governo federal em C\&T que foram de R $\$ 20.668,52$ milhões ao ano, constituídos por recursos desse Fundo, de incentivos fiscais da Lei do Bem, de contrapartidas da Lei de Informática e da Lei da Zona Franca de Manaus e de recursos de outros órgãos setoriais do Poder Executivo Federal. Ao incorporar os dispêndios estaduais, nesse mesmo período, a média do total dos dispêndios públicos em C\&T no Brasil foi de R \$ 30.201,39 milhões ao ano e, desse total, os dispêndios dos governos estaduais corresponderam a $31,56 \%$ ao ano, e os dispêndios do governo federal, $68,44 \%$.

Os dispêndios do FNDCT e os dispêndios dos governos estaduais, ambos destinados a ações não reembolsáveis de $\mathrm{C} \& \mathrm{~T}$, foram organizados na Tabela 01, por regiões brasileiras entre 2006 a 2013. Nesta seção, os dados dessa tabela foram desagregados por estados da federação, utilizando valores ou percentuais médios anuais, entre os anos de 2006 a 2013.

Conforme a Tabela 1, o total dos dispêndios dos governos estaduais foi de $\mathrm{R} \$ 9.532,87$ milhões ao ano e os dispêndios do FNDCT foram de R\$ 1.751,83 milhões ao ano, o que representou $18,38 \%$ do total dos dispêndios em C\&T dos estados.

A análise dos dados do FNDCT mostra que as regiões mais desenvolvidas economicamente recebem, em valores absolutos, a maior parcela dos recursos. Entretanto, quando se observa a representatividade dos dispêndios do FNDCT nos dispêndios de determinados governos estaduais, vê-se que os dispêndios do FNDCT são mais representativos para os estados de regiões menos desenvolvidas economicamente.

Tabela 1

Dispêndios dos governos estaduais e dos dispêndios do FNDCT, ambos em Atividades de Ciência e Tecnologia $(\mathrm{C} \& \mathrm{~T})^{(\mathrm{a})}$ por regiões brasileiras - 2006 a 2013

(em R \$ milhões correntes)

\begin{tabular}{l|c|c|c|c|c|c}
\hline \multirow{2}{*}{} & \multicolumn{2}{|c|}{2006} & \multicolumn{2}{c|}{2007} & \multicolumn{2}{c}{2008} \\
\cline { 2 - 7 } & $\begin{array}{c}\text { Dispêndios } \\
\text { FNDCT }\end{array}$ & $\begin{array}{c}\text { Dispêndios } \\
\text { Estaduais }\end{array}$ & $\begin{array}{c}\text { Dispêndios } \\
\text { FNDCT }\end{array}$ & $\begin{array}{c}\text { Dispêndios } \\
\text { Estaduais }\end{array}$ & $\begin{array}{c}\text { Dispêndios } \\
\text { FNDCT }\end{array}$ & $\begin{array}{c}\text { Dispêndios } \\
\text { Estaduais }\end{array}$ \\
\hline Centro-Oeste & 101,20 & 71,66 & 114,66 & 143,75 & 165,46 & 153,80 \\
\hline Nordeste & 150,25 & 441,66 & 195,30 & 515,20 & 240,94 & 732,46 \\
\hline Norte & 60,04 & 125,03 & 81,98 & 152,16 & 99,28 & 245,76 \\
\hline Sudeste & 529,17 & $3.141,80$ & 799,83 & $4.289,77$ & 875,35 & $5.225,42$ \\
\hline Sul & 116,63 & 501,94 & 177,12 & 586,56 & 243,03 & 780,58 \\
\hline Total & 957,29 & $4.282,10$ & $1.368,90$ & $5.687,43$ & $1.624,04$ & $7.138,00$ \\
\hline
\end{tabular}




\begin{tabular}{l|c|c|c|c|c|c}
\hline \multirow{2}{*}{} & \multicolumn{2}{|c|}{2009} & \multicolumn{2}{c|}{2010} & 2011 & \\
\cline { 2 - 7 } & $\begin{array}{c}\text { Dispêndios } \\
\text { FNDCT }\end{array}$ & $\begin{array}{c}\text { Dispêndios } \\
\text { Estaduais }\end{array}$ & $\begin{array}{c}\text { Dispêndios } \\
\text { FNDCT }\end{array}$ & $\begin{array}{c}\text { Dispêndios } \\
\text { Estaduais }\end{array}$ & $\begin{array}{c}\text { Dispêndios } \\
\text { FNDCT }\end{array}$ & $\begin{array}{c}\text { Dispêndios } \\
\text { Estaduais }\end{array}$ \\
\hline Centro-Oeste & 177,36 & 269,28 & 342,86 & 356,23 & 202,23 & 405,47 \\
\hline Nordeste & 220,38 & 938,82 & 373,21 & $1.296,60$ & 270,26 & $1.245,05$ \\
\hline Norte & 78,44 & 345,12 & 126,67 & 429,85 & 78,90 & 427,39 \\
\hline Sudeste & 808,28 & $5.871,09$ & $1.157,71$ & $6.936,81$ & 872,51 & $8.487,91$ \\
\hline Sul & 238,43 & $1.000,52$ & 401,25 & $1.182,31$ & 304,37 & $1.305,83$ \\
\hline Total & $1.522,89$ & $8.424,82$ & $2.401,69$ & $10.201,79$ & $1.728,27$ & $11.871,64$ \\
\hline
\end{tabular}

\begin{tabular}{l|c|c|c|c|c|c}
\hline \multirow{2}{*}{} & \multicolumn{2}{|c|}{2012} & \multicolumn{2}{c|}{2013} & \multicolumn{2}{c}{ Média 2006 a 2013 } \\
\cline { 2 - 7 } & $\begin{array}{c}\text { Dispêndios } \\
\text { FNDCT }\end{array}$ & $\begin{array}{c}\text { Dispêndios } \\
\text { Estaduais }\end{array}$ & $\begin{array}{c}\text { Dispêndios } \\
\text { FNDCT }\end{array}$ & $\begin{array}{c}\text { Dispêndios } \\
\text { Estaduais }\end{array}$ & $\begin{array}{c}\text { Dispêndios } \\
\text { FNDCT }\end{array}$ & $\begin{array}{c}\text { Dispêndios } \\
\text { Estaduais }\end{array}$ \\
\hline Centro-Oeste & 258,50 & 536,58 & 740,50 & 620,13 & 262,85 & 319,61 \\
\hline Nordeste & 217,42 & $1.538,93$ & 351,58 & $1.532,96$ & 252,42 & $1.030,21$ \\
\hline Norte & 49,42 & 515,06 & 114,43 & 587,27 & 86,15 & 353,45 \\
\hline Sudeste & 899,43 & $9.514,37$ & $1.048,24$ & $10.590,91$ & 873,81 & $6.757,26$ \\
\hline Sul & 326,16 & $1.545,62$ & 405,86 & $1.675,35$ & 276,61 & $1.072,34$ \\
\hline Total & $1.750,93$ & $13.650,56$ & $2.660,60$ & $15.006,60$ & $1.751,83$ & $9.532,87$ \\
\hline
\end{tabular}

Fonte: Assessoria de Acompanhamento e Avaliação Finalística (ASCAV/MCTIC) e Assessoria de Coordenação dos Fundos Setoriais (ASCOF/MCTIC).

Elaboração dos autores.

Entre 2006 e 2013, as representatividades anuais dos dispêndios do FNDCT nos dispêndios dos governos estaduais por região foram as seguintes: Centro-Oeste: $82,24 \%$, Nordeste $24,50 \%$, Norte $24,37 \%$, Sudeste $12,93 \%$ e Sul $25,79 \%$.

A abertura desses dispêndios dos governos estaduais e dos dispêndios do FNDCT por estados, mediante a análise da participação relativa, auxilia o melhor entendimento dessa representatividade e de sua contribuição para os entes federativos.

As participações relativas anuais dos dispêndios do FNDCT nos dispêndios dos governos estaduais, para, respectivamente, os estados com mais recursos destinados à C\&T, foram: São Paulo de 6,70\%; Rio de Janeiro de 54,26\%; Paraná de 12,06\%; Minas Gerais de 29,79\%; Bahia de 11,96\%; e Santa Catarina de 21,01\%.

No mesmo período, respectivamente, anualmente, as maiores participações relativas dos dispêndios do FNDCT nos dispêndios dos governos estaduais em C\&T foram: Amapá com 416,88\%; Distrito Federal com 194,43\%; Rio Grande do Sul com 69,77\%; Roraima com 64,29\%; Rio de Janeiro com 54,26\%; Alagoas com 51,39\%; Pernambuco com 43,01\%; e Sergipe com $39,92 \%$. 
Uma primeira conclusão sobre essa representatividade do FNDCT nos dispêndios dos estados é a sua importância para os entes federativos menos desenvolvidos economicamente, como os estados do Amapá, Roraima e Alagoas. Ao serem analisados os dados de forma mais acurada, vê-se que para São Paulo - que respondeu por 58,18\% dos dispêndios estaduais anuais em C\&T e que recebeu $21,22 \%$ dos dispêndios anuais do FNDCT - a participação dos dispêndios do FNDCT nos dispêndios do estado representou apenas 6,70\%.

Por outro lado, vê-se que para o Amapá - que respondeu por 0,10\% dos dispêndios estaduais anuais em C\&T e que recebeu 2,17\% dos dispêndios anuais do FNDCT - a participação dos dispêndios do FNDCT nos dispêndios do estado representou 416,88\%. Vê-se ainda que para Alagoas - que respondeu por $0,24 \%$ dos dispêndios estaduais anuais em C\&T e que recebeu $0,67 \%$ dos dispêndios anuais do FNDCT - a participação dos dispêndios do FNDCT nos dispêndios do estado representou 51,39\%.

Esses dados mostram que a representatividade do FNDCT constituiu um pré-requisito importante para o atendimento do princípio da autonomia dos estados menos desenvolvidos economicamente. Não para casos como o de São Paulo, no qual as atividades de C\&T poderiam ser realizadas independentemente dos recursos do FNDCT. Mas para estados como Amapá e Alagoas, que tiveram dispêndios próprios em $\mathrm{C} \& \mathrm{~T}$ muito baixos e receberam conjuntamente apenas $2,84 \%$ do total dos recursos do FNDCT - mas isso representou mais da metade do total dos dispêndios em C\&T em Alagoas e mais de quatro vezes no Amapá - este fundo assegura a execução das atividades de C\&T.

Não se pode afirmar, contudo, que a simples repartição regional de recursos do FNDCT seja suficiente para considerar, no arranjo político-institucional da sua governança, a perspectiva do federalismo quanto à observância do princípio da autonomia. Isso porque, diferentemente de outras áreas ou sistemas de políticas públicas, como Saúde, Educação e Assistência Social - em que há transferência de recursos entre entes e, simultaneamente, gestão compartilhada, ainda que persistam deficiências administrativas na integração dos entes federativos (Pereira Júnior; Campos, 2014) -, o FNDCT destina recursos diretamente a projetos ou instituições, porém, desacompanhado da participação dos entes subnacionais, como será discutido na próxima seção.

\subsection{Quanto ao princípio da participação}

Para o exame da observância (ou inobservância) do princípio da participação no arranjo político-institucional da governança do FNDCT, esta seção utilizou a técnica de pesquisa documental - especificamente de Leis, Decretos e das principais Portarias - nos dezesseis

programas que compõem o FNDCT, além das Instruções Normativas do Conselho Diretor do FNDCT.

O arranjo político-institucional original da governança do FNDCT foi estabelecido nas reformas de 1999-2002 pelas leis e regulamentos dos Programas e Fundos Setoriais de C\&T, e pela Lei n. 10.197, de 14/02/2001, que alterou as fontes de receitas e as destinações dos recursos do FNDCT (criado pelo Decreto-Lei n. 719 de 31/07/1969 e restabelecido pela Lei 8.172 de 18/01/1991). Nesse arranjo original, havia apenas duas instâncias decisórias: i) o 
Comitê Gestor Interministerial, instituído pela Lei n. 10.197/2001, e que foi substituído pelo Conselho Diretor a partir da Lei n. 11.540 de 12/11/2007; e ii) os Comitês Gestores de Programas e Fundos Setoriais que foram instituídos individualmente pelas respectivas leis criadoras dos programas setoriais e que foram mantidos a partir da Lei n. 11.540 de 12/11/2007, apesar de terem perdido muitas das suas competências originárias.

A partir de 2007, como indicado na legenda da Figura 01, foram aprovadas - mediante a Lei n. 11.540 de 12/11/2007 e as Instruções Normativas do Conselho Diretor n. 2 e n. 3, ambas de 22/12/2010 - grandes mudanças no arranjo político-institucional original da governança do FNDCT. A partir dessas mudanças, o arranjo político-institucional da governança do FNDCT culminou na seguinte estrutura decisória:

a) um conselho diretor do FNDCT;

b) um comitê de coordenação executiva;

c) um comitê de coordenação dos programas e fundos setoriais;

d) 14 comitês gestores de programas e fundos setoriais; e

e) por 2 comitês gestores de programas e fundos não setoriais (CT-Infra e CT-VerdeAmarelo).

Com essa estrutura, o arranjo político-institucional da governança do FNDCT assume uma composição, mediante estimativa de Brasil (2017, p. 24), com mais de 150 representantes, além da Financiadora de Estudos e Projetos (FINEP) como secretaria executiva do FNDCT. A Figura 1 apresenta as principais alterações institucionais entre 2001 e 2007 e algumas de competências administrativas das instituições da estrutura decisória do FNDCT.

Figura 1

Estrutura decisória das destinações dos recursos do FNDCT

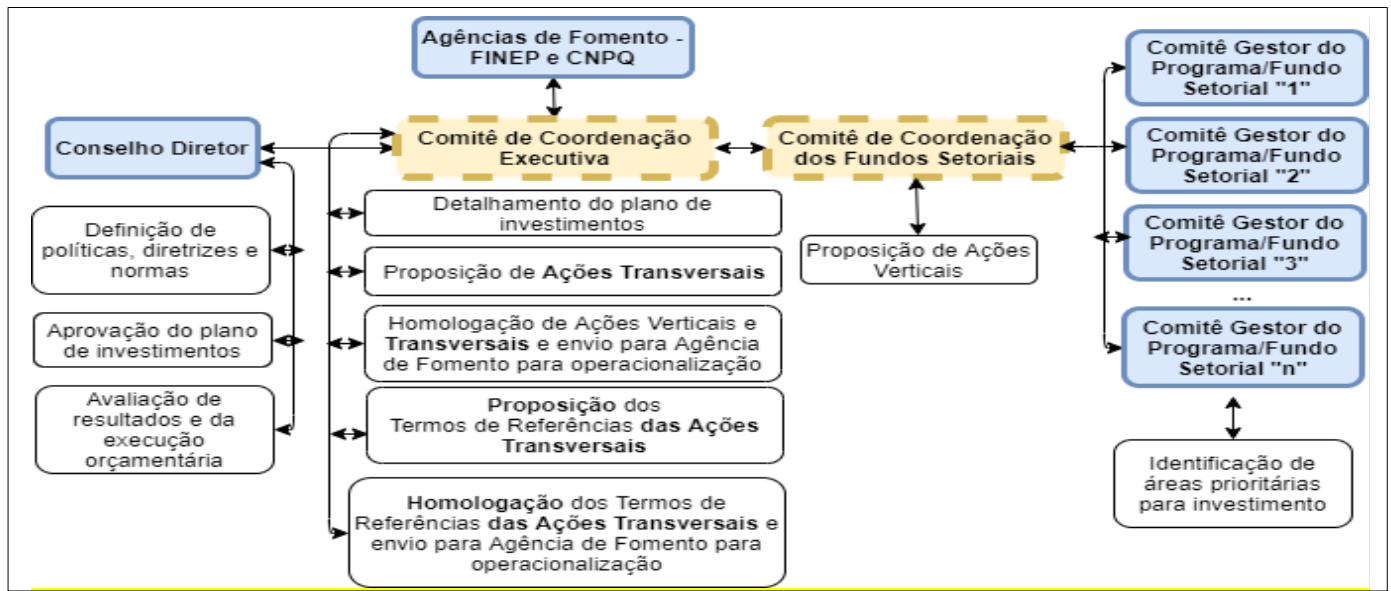

\section{Legenda}

Instâncias decisórias anteriores à Portaria MCTI n. 151/2004 e à Lei n. 11.540/2007:

Instâncias criadas a partir da Portaria MCTI n. 151/2004 e da Lei n. 11.540/2007:

Competências:

Fonte: Elaboração dos autores. 
O Conselho Diretor foi instituído pela Lei n. 11.540 de 12/11/2007, em substituição ao Comitê Gestor Interministerial, estabelecido pela Lei n. 10.197/2001. A administração do FNDCT, atribuída a esse conselho, ficou presidida pelo Ministro do MCTIC e integrada por representantes de alguns ministérios setoriais (Educação, Desenvolvimento e Indústria, Defesa etc.), pelos presidentes da FINEP, do Conselho Nacional de Desenvolvimento Científico e Tecnológico (CNPq), do Banco Nacional do Desenvolvimento Econômico e Social (BNDES) e da Empresa Brasileira de Pesquisa Agropecuária (Embrapa), além de representantes do setor empresarial, da comunidade científica e tecnológica e dos trabalhadores da área de ciência e tecnologia, mas sem representações subnacionais.

O artigo $5^{\circ}$ da Lei n. 11.540/2007 definiu como atribuições do Conselho Diretor, dentre outras, as competências de recomendar aos Comitês Gestores, em relação aos recursos destinados por lei em programação específica, medidas destinadas a compatibilizar e articular as políticas setoriais com a Política Nacional de C\&T, por meio de ações financiadas com recursos do FNDCT e com recursos das "ações transversais".

Embora não previsto na Lei n. 11.540/2007, o Comitê de Coordenação Executiva foi instituído pela Instrução Normativa do Conselho Diretor n. 2 de 22/12/2010 - composto "exclusivamente" (conforme art. 15 dessa instrução) pelo Secretário Executivo e secretários do MCTIC, além dos presidentes da Finep e do CNPq. Dentre as competências atribuídas pela Instrução Normativa n. 2/2010, destacaram-se: identificar e recomendar as áreas prioritárias para a aplicação dos recursos das ações setoriais e submeter à aprovação dos Comitês Gestores e Comitê de Coordenação; coordenar a elaboração dos termos de referência das "ações transversais", e aprová-los e encaminhá-los às agências para elaborações de editais, chamadas públicas e encomendas mediante ações "transversais" e "verticais"; e articular e coordenar o acompanhamento e avaliação geral das ações do FNDCT.

O Comitê de Coordenação dos Fundos Setoriais - outra alteração trazida pela Lei n. 11.540/2007 e cuja presidência foi atribuída ao MCTIC - ficou composto pelos presidentes dos Comitês Gestores, pelos presidentes da FINEP e do CNPq. Entretanto, a Lei n. 11.540/2007 não estabeleceu as competências desse Comitê, que foram estabelecidas pela Instrução Normativa do Conselho Diretor n. 2 de 22/12/2010. Dentre as competências atribuídas a esse Comitê estão as de: promover a gestão operacional integrada das ações setoriais com o apoio da Assessoria de Coordenação dos Fundos Setoriais (ASCOF/MCTIC); coordenar a elaboração dos planos de investimentos para detalhamento pelos Comitês Gestores; coordenar a elaboração e aprovar os termos de referência das ações setoriais; elaborar termos de referência para orientar à utilização dos recursos destinados no orçamento para as ações setoriais e submeter à deliberação do Comitê de Coordenação Executiva.

Os Comitês Gestores dos Fundos Setoriais, instâncias decisórias originárias do FNDCT, foram instituídos individualmente pelas respectivas leis criadoras dos programas setoriais. Em geral, a composição dos Comitês Gestores inclui um representante do MCTIC, que o preside; representantes dos ministérios; de agências reguladoras e de empresas públicas 
ligadas ao setor específico, além de representantes dos setores industrial e acadêmico. Dentre as competências desses comitês, estão as de definir diretrizes e o plano anual de investimentos; acompanhar a implementação de ações; e avaliar os resultados. Uma vez definidas as ações, suas implementações ficariam a cargo dos agentes executores: a FINEP e o CNPq.

A Lei n. 11.540/2007 atribuiu ao Conselho Diretor amplas competências para decidir sobre a alocação dos recursos nas "ações transversais". Entretanto, muitas dessas competências foram delegadas ao Comitê de Coordenação Executiva, principalmente pelas Instruções Normativas do Conselho Diretor n. 2 e n. 3, ambas de 22/12/2010. Destaca-se, em especial, a atribuição de elaborar e de aprovar os termos de referência dessas "ações transversais", destacadas na Figura 01. Na execução, esse Comitê elege discricionariamente (sem diretrizes estabelecidas em lei ou pelo Conselho Diretor) setores ou áreas para ações transversais, sem vinculação com os programas setoriais de $\mathrm{C} \& \mathrm{~T}$, estabelecidos em lei (inclusive para substituir o orçamento do MCTIC destinado a custeio), comprometendo, nos últimos dez anos, mais de $50 \%$ do total dos recursos não reembolsáveis do FNDCT, segundo dados do SIAFI. Também se tornou relevante o poder do Comitê de Coordenação Executiva nas "ações verticais", competência que originariamente foi atribuída aos Comitês Gestores dos programas e fundos setoriais.

Assim, o Comitê de Coordenação Executiva tornou-se o centro de poder decisório das destinações do FNDCT, à medida que assume competências sobre ações transversais, bem como, sobre as ações verticais, refletindo o aumento do poder - de última instância decisória da FINEP, do CNPq e do MCTI, únicos com representações nesse comitê.

A presença dos presidentes dos Comitês Gestores no Comitê de Coordenação dos Fundos Setoriais trazia a expectativa de tornar-se o principal colegiado de governança dos programas e fundos setoriais. Ao longo dos anos, todavia, a presidência desses comitês acabou sendo ocupada, sem rotatividade, por secretários ou servidores do MCTIC, desaparecendo o intento da gestão compartilhada com representações setoriais.

Da perspectiva do federalismo, essa perda de poder das representações setoriais de C\&T dificultou o avanço para considerar representações regionais em correspondência às regionalizações de recursos do FNDCT previstas na criação dos programas e fundos setoriais de CT\&I. Nenhuma das instâncias decisórias do arranjo político-institucional da governança do FNDCT incorporou o poder político de representações subnacionais, tampouco o atendimento das demandas subnacionais, veiculadas pelo Confap e Consecti, instituições reconhecidas pela Portaria MCT n. 731 de 20/11/2007, portaria decorrente do termo de cooperação firmado entre MCT, Consecti e Confap em dezembro de 2006 para implementação da agenda regional de C\&T.

Mesmo na última instância, no Conselho Diretor - apesar de ser um colegiado composto por órgãos setoriais importantes politicamente do Poder Executivo Federal, como Ministério da Defesa - frustraram-se as expectativas de incluir o poder das representações 
setoriais e também a inclusão de uma agenda regional de C\&T com representação subnacional, porventura o Ministério da Integração Nacional.

Para resumir, a dimensão federativa, ensaiada originalmente para os programas setoriais de C\&T, nas reformas entre 1999 e 2002, como já assinalado, fundamentava-se no princípio da gestão compartilhada da destinação de recursos. O FNDCT, contudo, perdeu com alterações de estrutura decisória (Lei n. 11.540/2007 e instruções normativas), o poder da representatividade setorial. Perdeu também a oportunidade histórica de inserir uma agenda regional de C\&T com representação subnacional, para equilibrar o jogo das forças decisórias, tanto do lado da arrecadação quando do lado da destinação de recursos - prejudicada por alterações legais "em favor" do MCTIC, CNPq e Finep.

Pode-se imaginar, assim, que o fortalecimento político-institucional com presença conjunta de representações setoriais e subnacionais permitiria: equilibrar o poder nas decisões para arrecadação de recursos (fontes de receita, orçamento e execução fiscal) e amenizar a instabilidade dos fluxos de recursos e a perda de fontes como a do CT-Petro (royalties da exploração de Petróleo e Gás). Mas o declínio de participação setorial e ausência de participação subnacional no poder decisório deixou o FNDCT exposto a fatores geradores de crise, originados no próprio Poder Executivo Federal, dentre os quais: a prática de substituição de fontes e contingenciamentos injustificados.

Com o poder decisório concentrado no MCTIC, CNPq e Finep (no âmbito do Comitê de Coordenação Executiva), perdeu-se oportunidades de equilibrar o poder decisório do FNDCT para enfrentar crises fiscais como a atualmente vivenciada pelo Estado brasileiro. Uma crise que atinge toda a federação, como se pode perceber no declínio de repasses de recursos das agências federais para as fundações estaduais de amparo à pesquisa e secretarias estaduais de ciência e tecnologia, atores que deveriam ter representações no arranjo político-institucional da governança do FNDCT (Marques, 2017).

É nesse sentido que se pode falar de um processo de fragilização do arranjo políticoinstitucional da governança do FNDCT, causado pela não observância dos princípios federativos (especialmente de autonomia e participação subnacional, mas também setorial), culminando nos anos recentes em perdas de importantes fontes de receitas, crescentes contingenciamentos e desorganização orçamentária, e à luz dos julgados do TCU, no desvirtuamento nas destinações, dispersão de recursos em vários projetos desconexos. ${ }^{6} \mathrm{~A}$ próxima seção avança na análise e sustenta a hipótese de que esse processo de fragilização contribuiu para uma crise sem precedente do FNDCT.

(6) O Tribunal de Contas da União constatou esse desvirtuamento nas destinações dos recursos do FNDCT via substituição de fontes pelos seguintes julgados: Acórdão n. 3081-53/2008- Plenário; TC n. 015.995/2012-7 que resultou no Acórdão n. 3.440/2013-TCU-Plenário; TC n. 025.520/2013-0 que resultou no Acórdão n. 1.232/2014-TCU-Plenário; Acórdão n. 500-8/2015-TCU-Plenário. 


\section{Crise e futuro do FNDCT: consequências da não observância dos princípios federativos}

Sobre as consequências da inobservância dos princípios federativos na governança do FNDCT, pode-se levantar a hipótese de que essa ausência contribuiu para a crise atual desse Fundo, marcada, por um lado, por desvios das finalidades originárias da destinação dos recursos, atribuídas pelas leis dos programas setoriais, por outro, pela grande instabilidade e perdas de receitas. Argumenta-se que vigora um processo de fragilização do arranjo políticoinstitucional da governança do FNDCT.

Com a crise fiscal e financeira do Estado nos últimos anos, a partir de 2014, o Senado Federal manifestou-se sobre a crise financeira do FNDCT, e passou a realizar audiências públicas na Comissão de Ciência, Tecnologia, Inovação, Comunicação e Informática (CCTICI). Como resultado de audiências realizadas em 08/11/2016, 22/11/2016 e 06/12/2016, foi publicado o Relatório de Avaliação de Políticas Públicas dos Fundos de Incentivo ao Desenvolvimento Científico e Tecnológico (Brasil, 2016).

Essas audiências públicas enfatizaram, como principais fatos geradores da crise do FNDCT, contingenciamentos de recursos e desvios de finalidades nas suas aplicações. A comunidade científica, conforme Marques (2017), também percebe a crise do FNDCT como derivada de contingenciamentos, e do fato de os "fundos setoriais terem sido usados para tapar buracos do orçamento do MCTIC, o que não era a função original desses recursos" (Marques, 2017, p. 26).

Esse debate, todavia, não está enfatizando a crise em questão como consequência da fragilização do arranjo político-institucional de sua governança, resultante, como atestado na seção 2: da combinação da perda de representações setoriais com ausência de representações entes subnacionais. Para defender essa hipótese, relaciona-se a seguir os fatos geradores da crise do FNDCT à fragilização mencionada.

\subsection{Fatos geradores da crise do FNDCT}

A crise do FNDCT se manifesta pelo lado da arrecadação de recursos, com crescente instabilidade dos fluxos anuais de recursos e perdas de fontes de receita e, pelo lado das destinações, com desvios das finalidades originárias dos recursos do Fundo atribuídas pela legislação dos programas setoriais.

Dentre os principais fatos geradores da crescente instabilidade dos fluxos anuais de recursos e perdas de fontes de receitas do FNDCT, podem ser citados:

a) os impactos, após a arrecadação, na disponibilidade de recursos para o FNDCT devido à incidência da Desvinculação de Receitas da União (DRU). A DRU passou a incidir na destinação do FNDCT a partir da Emenda Constitucional n. 42 de 19/12/2003, desvinculando $20 \%$ dos recursos arrecadados destinados para áreas não previstas nas legislações dos programas setoriais de C\&T. A partir da Emenda Constitucional n. 93 de 
2016, o percentual de desvinculação de receitas do FNDCT subiu de $20 \%$ para $30 \%$ das arrecadações desse Fundo;

b) a aprovação das dotações nas Leis Orçamentárias Anuais (LOAs) com valores menores do que as efetivas arrecadações dos recursos. Segundo dados do SIAFI, esse primeiro corte nos recursos do FNDCT chegou, em alguns anos, a exemplo de 2016, a superar $42 \%$ dos recursos efetivamente arrecadados pelo FNDCT, já descontados os valores retirados pela DRU, como mostra a Figura 2;

c) os contingenciamentos propriamente $\operatorname{ditos}^{7}$ dos recursos do FNDCT, mediante Decreto do Poder Executivo Federal. Segundo dados do SIAFI, esse contingenciamento resultou, em alguns anos, a exemplo de 2016, em perdas superiores a $60 \%$ das dotações anuais nas LOAs. A dotação, na LOA, no final do exercício financeiro de 2016 chegou a apenas $27,69 \%$ do valor efetivamente arrecadado pelo FNDCT no ano, como mostra a Figura 02, sem considerar os "restos a pagar", valores em muitos anos cobertos com recursos do orçamento do ano seguinte.

Figura 2

Perdas de recursos do FNDCT via contingenciamentos e via aprovação das dotações nas LOAs com valores menores do que as efetivas arrecadações

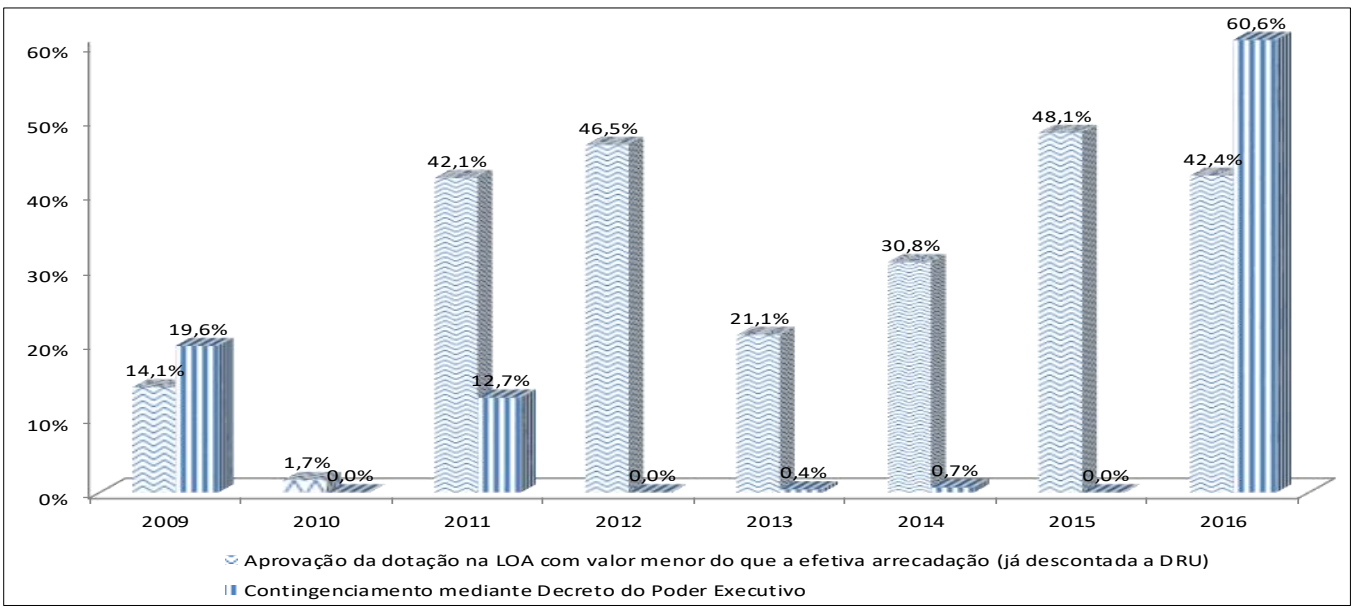

Fonte: Dados do SIAFI e elaboração dos autores.

a) como corolário do contingenciamento, as retiradas de recursos do FNDCT para pagamentos de despesas primárias ou amortização da dívida pública. Segundo o Acórdão n. 2.000/2012 - TCU - Plenário, houve quatro retiradas de recursos para pagamentos de despesas primárias ou para amortização da dívida pública: R\$ 252 milhões em 2002, R\$ 238 milhões em 2003, R \$ 4,3 bilhões em 2008 e R\$ 1,7 bilhão em 2010; totalizando

(7) A prática de contingenciamento das dotações do FNDCT foi constatada pelo TCU nos seguintes julgados: Acórdão 3081/2008 - TCU - Plenário; TC-002.105/2012-8 que resultou no Acórdão n. 2000/2012 - TCU - Plenário; Acórdão n. 3440/2013 - TCU - Plenário. 
nesses anos R $\$ 6,5$ bilhões. Segundo Brasil (2016, p. 109), se não tivessem ocorrido essas retiradas, o saldo financeiro do FNDCT, ou seja, os recursos não executados do FNDCT e acumulados na Conta Única da União seriam superiores a R $\$ 16$ bilhões (em 2017) e não os $\mathrm{R} \$ 10,00$ bilhões que se encontram atualmente;

b) a autorização para alterações nos marcos legais de setores regulados, que implicaram perdas de fontes de receitas (como as dos royalties do petróleo pela Lei n. 12.858 , de 09/09/2013, quando representavam cerca de 50\% do total da arrecadação do FNDCT). A partir de 2014, as ações em execução pelo CT-Petro passaram a ser supridas por parcos recursos ordinários do Tesouro, fonte 100, e pela utilização de superávit financeiro de exercícios anteriores do próprio fundo;

c) as taxas de administração e custeio de despesas operacionais das operações do FNDCT cobrado pela FINEP, como secretaria executiva, acima dos percentuais estabelecidos em lei. O Acórdão n. 3.081/2008 - TCU - Plenário identificou desempenho pela FINEP de atribuições que extrapolam a função de Secretaria Executiva do FNDCT, passando, ela mesma, a decidir sobre aspectos da gestão do fundo, a exemplo das regras referentes à internalização de recursos, disciplinadas por resoluções da diretoria da empresa, e não por normativos emitidos pelo próprio FNDCT, o que resultou em cobranças pela FINEP pelos seus serviços em percentuais acima dos estabelecidos em lei;

d) impacto no orçamento futuro do FNDCT da Emenda Constitucional n. 95/2016, que estabelece limites dos gastos públicos para os próximos 20 anos, criando expectativas de interrupções das atividades de CT\&I, atividades que exigem estabilidade no longo prazo dos fluxos de recursos;

Dentre os principais fatos que levaram aos desvios das finalidades originárias dos recursos do FNDCT, podem ser citados:

a) a prática de substituição de fontes ${ }^{8}$, ou seja, a destinação de recursos do FNDCT para ações desvinculadas das finalidades dos programas setoriais de CT\&I, como as destinações ao Programa Ciência Sem Fronteiras, a contratos de gestão firmados entre o MCTIC e organizações sociais e destinações a ações próprias do MCTIC; e,

b) o avanço da discricionariedade na execução dos recursos do FNDCT via ações transversais ${ }^{9}$ no âmbito do MCTIC, ao arrepio das leis que criaram os programas setoriais, o que é não apenas um desvirtuamento da destinação dos recursos do FNDCT, mas também uma dispersão dos recursos em vários projetos desconexos e que não se articulam para um objetivo maior comum. Nos últimos dez anos, as execuções dessas ações transversais têm

(8) A prática da substituição de fontes do FNDCT foi constatada pelo TCU nos seguintes julgados: Acórdão n. 308153/2008 - Plenário; TC n. 015.995/2012-7 que resultou no Acórdão n. 3.440/2013-TCU-Plenário; TC n. 025.520/2013-0 que resultou no Acórdão n. 1.232/2014-TCU-Plenário; Acórdão n. 500-8/2015-TCU-Plenário.

(9) O desvirtuamento do FNDCT via ações transversais foi constatado pelo TCU nos seguintes julgados: Acórdão n. 686/2005 - TCU - Plenário; Acórdão n. 3081/2008 - TCU - Plenário; TC-002.105/2012-8 que resultou no Acórdão n. 2000/2012 - TCU - Plenário; TC n. 015.995/2012-7 que resultou no Acórdão n. 3440/2013 - TCU - Plenário. 
comprometido mais de 50\% do total dos recursos não reembolsáveis do FNDCT. Segundo Brasil (2016, p. 87), no ano de 2015, as ações transversais representaram $90 \%$ da execução do FNDCT;

Diante desses fatos subjacentes à crise do FNDCT, constata-se que o arranjo políticoinstitucional da sua governança, analisada na seção 2, foi insuficiente em termos de representação política setorial e subnacional para assegurar que o Poder Executivo e o Poder Legislativo:

a) exercessem papel conjunto em decisões em relação à arrecadação de recursos (fontes de receita, orçamento e execução fiscal) e às destinações, sobretudo, em relação a aprovações de normativos que, em vez de produzir efeitos deletérios, pudessem manter o fluxo de arrecadações e destinações anuais de recursos de acordo com as finalidades originárias estabelecidas pelas leis dos programas setoriais; e,

b) observassem, ainda que não explícitos na Constituição Federal ou no marco legal vigente da área de CT\&I, os princípios do federalismo na coordenação setorial e subnacional da arrecadação e destinação de recursos.

\subsection{A crise do FNDCT como consequência da fragilização político-institucional da governança da Política Nacional de CT\&I} resumida:

A fragilização da governança do FNDCT, conforme descrito na seção 2, pode ser assim

a) repartição regional de recursos sem correspondente participação dos entes subnacionais;

b) enfraquecimento das representações dos setores produtivos nos Comitês Gestores dos Fundos Setoriais;

c) perda de competências do Conselho Diretor mediante atos normativos infralegais, como a Instrução Normativa do Conselho Diretor n. 2/2010, que criou o Comitê de Coordenação Executiva;

d) assunção do Comitê de Coordenação Executiva como centro de poder da governança do fundo, assumindo várias das competências ${ }^{10}$ que haviam sido atribuídas, mediante lei, ao Conselho Diretor; e,

(10) A CCTICI do Senado sugeriu corrigir essas delegações mediante decreto legislativo: "Essa situação, a delegação de atribuições legalmente conferidas ao Conselho Diretor do FNDCT ao Conselho de Coordenação Executiva, realizada por meio da Instrução Normativa n. 2/2010, do Conselho Diretor do FNDCT, deve ser corrigida por meio de decreto legislativo. Nada obsta a criação do referido Conselho de Coordenação Executiva, ou que este atue subsidiando o Conselho Diretor. Entretanto, não podem as atribuições do Conselho Diretor serem delegadas a outra entidade, com composição substancialmente distinta, sob pena de se perder a característica de representatividade plural do processo decisório fixada em lei” (Brasil, 2016, p. 111, grifos nossos). 
e) aumento de poder do MCTIC, FINEP e do CNPq, mediante o Comitê de Coordenação Executiva, nas decisões sobre a alocação de recursos de forma desproporcional às transversalidades e representatividades setoriais, e sem diretrizes e metas, conforme Acórdão n. 3440/2013 - TCU - Plenário, que determinou ao Conselho Diretor a elaboração de diretrizes e metas para a execução dos recursos, determinação essa ainda não cumprida segundo Brasil (2016, p. 92).

Do lado da destinação de recursos, esse processo de fragilidade político-institucional fica ainda mais evidente quando se verifica que os atos normativos infralegais - que fortaleceram o Comitê de Coordenação Executiva, em detrimento do Conselho Diretor e dos Comitês Gestores dos fundos - mudaram o centro de poder da governança do FNDCT. Originalmente, esse poder era compartilhado entre o Conselho Diretor, o Comitê de Coordenação e os Comitês Gestores dos fundos, e acabou circunscrito ao MCTIC, FINEP e CNPq.

Isto posto, como compreender a crise do FNDCT como consequência dessa fragilização? $\mathrm{Na}$ abordagem do federalismo brasileiro, essa questão pode ser respondida a partir da observação das características do federalismo brasileiro estabelecidas pela Constituição Federal de 1988 - CF/88, que podem ser ilustradas pela abordagem de Souza (2005):

Apesar das controvérsias sobre as principais características dos sistemas federativos, existe um consenso de que essa instituição tem duas dimensões principais: desenho constitucional e divisão territorial de poder governamental. Embora outros fatores e instituições também sejam objeto de análise sob a ótica do federalismo, tais como as dinâmicas da economia política, da competição partidária e da chamada cultura política, as manifestações territoriais do federalismo requerem uma análise não apenas de sua aplicação prática, mas também do ponto de vista das constituições. Essas manifestações territoriais dizem respeito à divisão de competências entre os entes constitutivos e no poder Legislativo, ao papel do poder Judiciário, à alocação de recursos fiscais e de responsabilidades entre os entes constitutivos da federação e suas garantias constitucionais (Souza, 2005, p. 105, grifos nossos).

Ainda na abordagem de Souza (2005), essas características revelam a ausência de mecanismos institucionais que estimulem a cooperação no federalismo brasileiro, intensamente competitivo, e não cooperativo:

Apesar de a Constituição prover vários mecanismos que sinalizam no sentido do federalismo cooperativo, tais como as competências concorrentes acima mencionadas [artigo $24 \mathrm{da} \mathrm{CF} / 88$ ], o federalismo brasileiro tende a ser altamente competitivo e sem canais institucionais de intermediação de interesses e de negociação de conflitos (Souza, 2005, p. 114, grifos nossos).

Nesse sentido, a CF/88 não atribui ao Poder Executivo Federal, composto pelo Presidente da República e pelos ministros de estados, canais institucionais para exercer 
competências de coordenação, embora haja institucionalidades dessa natureza estabelecidas, principalmente mediante lei, para as políticas de Saúde, Educação e Assistência Social.

Em relação ao Poder Legislativo Federal, Théret (2015) enfatiza o Senado brasileiro como sendo a instituição que mais teria poderes no sistema de freios e contrapesos para equilibrar as forças entre os poderes:

El Senado es en Brasil la institución que detenta más poderes en el sistema de frenos y contrapesos a la institución presidencial: el Senado tiene competencia exclusiva en 12 áreas. Por ejemplo, designa directamente a dos tercios de los jueces que revisan el gasto federal y tiene el derecho de negar o confirmar al otro tercio. El Senado tiene competencia exclusiva para autorizar los préstamos que piden los estados e ignorar una opinión negativa del Banco Central. El Senado tiene competencia exclusiva para aprobar los niveles de préstamo que la administración central solicita al exterior. En Brasil no hay un área política que esté más allá de la competencia de formulación de políticas del Senado, pero hay muchas áreas políticas que son prerrogativas de legislación exclusivas del Senado (Théret, 2015, p. 209).

Apesar dessa importância, concorda-se com Souza (2005) que o Senado também não possui canais institucionais para exercer competências para estimular a coordenação e a colaboração na execução das políticas públicas dentro e entre os poderes e desses com os entes federados, resumindo-se, na leitura de Souza (2005, p. 108) a um "órgão colaborador da Câmara dos Deputados".

Em abordagem aderente à de Souza (2005), Santos (1997) destacou que as chances de cooperação das ações entre os Poderes Executivo e Legislativo são menores em áreas com diversificados interesses:

É razoável supor também que quanto maiores e mais diversificados os interesses envolvidos, e quanto maior a importância estratégica dos atores em jogo, o que varia com a issue area em foco, menores são as chances de que se estabeleçam padrões de interação de natureza cooperativa entre o Executivo e o Legislativo (Santos, 1997, p. 12, grifos nossos).

A partir dessas características político-institucionais do federalismo e das políticas públicas brasileiros, pode-se afirmar que as fragilidades da governança do FNDCT refletem a descoordenação das ações dentre e entre os Poderes Executivo e Legislativo, evidenciadas quando esses poderes deixaram de exercer papéis conjuntos em decisões que afetaram a estabilidade da arrecadação de recursos, provocaram perdas de fontes de receitas e, sobretudo, decisões que autorizam destinações de recursos com desvios das finalidades originárias dos programas e fundos setoriais de C\&T.

O curioso é que o legislador constitucional, certamente já prevendo a descoordenação das ações dos Poderes Executivo e Legislativo nas políticas públicas, estabeleceu no parágrafo único do artigo 23 da CF/88 dispositivo para melhorar essa coordenação: "lei complementar fixará normas para a cooperação entre a União e os Estados, Distrito Federal e os Municípios, 
tendo em vista o equilíbrio do desenvolvimento e do bem-estar em âmbito nacional" (Brasil, 1988). No entanto, essa lei nunca foi proposta pelo poder Executivo ao Congresso Nacional.

Essa regulamentação constitucional permitiria aos poderes fortalecer o arranjo político-institucional da governança das políticas públicas, como a Política Nacional de CT\&I, ao exemplo do FNDCT, ao obrigar: a participação dos entes subnacionais na governança da Política, inclusive com supervisão do Senado Federal; reinstituição das representações efetivas dos setores produtivos nos comitês de decisão da Política, como os Comitês Gestores dos fundos setoriais; e, definição de regras, objetivos e metas para a governança da destinação e da arrecadação estável de recursos. Isso pressuporia articulação dentre e entre os Poderes Executivo e Legislativo federais e subnacionais, constituindo, por conseguinte, um poder unívoco e uníssono de contenção de fatores geradores de crises, como os vivenciados atualmente.

\subsection{Algumas considerações sobre o futuro do FNDCT}

A CCTICI do Senado Federal retomou - nas audiências realizadas em 08/11/2016, 22/11/2016 e 06/12/2016 - algumas ideias já tratadas nas reformas dos fundos setoriais ocorridas entre 1999 e 2002, como a necessidade de arrecadação estável de recursos no longo prazo para as atividades de CT\&I:

A importância do fluxo sustentado de recursos para projetos da área pode ser facilmente compreendida quando se lembra, por exemplo, que a formação de um doutor leva em média mais de 4 anos para ser concluída e que, por isso, a eventual interrupção de bolsas de doutorado e ou de financiamentos de projetos de pesquisa (...) pode obrigá-los a abandonar sua formação. Note-se que, nesses casos, a própria retomada dos projetos de pesquisa poderá ser comprometida ou inviabilizada pelo afastamento do pesquisador que passou anos estudando o tema, dominando as suas técnicas e testando caminhos para o seu desenvolvimento (Brasil, 2016, p. 30).

Sobre o desafio da estabilidade dos fluxos de recursos para as atividades de CT\&I, motivações das reformas dos fundos setoriais de 1999 a 2002, pode-se considerar como referência o exemplo da Fapesp. No Estado de São Paulo, a estabilidade da arrecadação é garantida há muitos anos: o artigo 123 da Constituição de São Paulo de 1947 passou a determinar $0,5 \%$ da receita ordinária do Estado à pesquisa científica. A Lei n. 5.918, de 18/10/1960, lei orgânica da Fapesp, e o Decreto n. 40.132, de 23/05/1962, estatuto da FAPESP, regulamentam essa determinação constitucional. Não por acaso, as atividades de C\&T de São Paulo independem dos recursos do FNDCT, como mostrou a Tabela 1 da seção 2.1.

Atualmente, surgem discussões e algumas propostas para alterar as legislações do FNDCT. Há por exemplo o Projeto de Lei Complementar de 2017, que propõe que os recursos consignados nas LOAs ao FNDCT não possam ser contingenciados pelo Poder Executivo. Há ainda discussões no âmbito do Poder Executivo para transformar o FNDCT em um fundo 
financeiro ${ }^{11}$. Essa proposta resolveria o problema dos contingenciamentos do Poder Executivo, mas não resolveria o problema da aprovação das dotações orçamentárias nas LOAs com valores menores do que as efetivas arrecadações dos recursos.

Entretanto, permanece a ausência nos debates políticos da necessidade de fortalecer o arranjo político-institucional da governança do FNDCT. Nenhuma das propostas em discussão aborda a dimensão político-institucional da governança numa perspectiva federativa, se não pelo artigo 23 da CF/88, por razões acima mencionadas, pelo art. 219-B da EC n. 85/2015, que estabelece a previsão legal para se efetivar a colaboração dos entes federativos na construção do Sistema Nacional de CT\&I.

Nesse sentido, pode-se afirmar que o futuro do FNDCT dependerá da observância dos princípios federativos. Além da observância do princípio da participação, da repartição de recursos entre entes federados, deverá ser considerado o princípio da cooperação inter-regional mediante incorporação na legislação de regras de contrapartida a serem aplicadas aos estados mais desenvolvidos, como o desenvolvimento de projetos em conjunto entre instituições de pesquisas, especialmente as universidades dos estados mais desenvolvidos com as dos menos desenvolvidos economicamente.

Entende-se que o desenvolvimento de programas e projetos de CT\&I em cooperação entre instituições federativas irá propiciar aos entes menos desenvolvidos superar desafios, não apenas de fontes de receitas e arrecadação de recursos, mas também de infraestrutura de ensino e pesquisa, e especialmente, de capacidade de desenvolvimento e gestão de projetos de interesse nacional. Em concordância com Brito Cruz (2012), a colaboração ou cooperação interinstitucional entre as esferas federal e estadual poderia ser "vencedora":

Geridas pelos Estados, em regime de autonomia já praticado em São Paulo, as novas universidades, financiadas colaborativamente pelas esferas estadual e federal, poderiam adaptar-se às características locais sem estar presas à camisa de força e à lentidão do governo federal. Já se faz isso na saúde com o SUS e na educação básica com o Fundef: financiamento federal e local (estadual, municipal e até privado) para cumprir objetivos de alto interesse público (Brito Cruz, 2012. p. 2, grifos nossos).

\section{Conclusões}

Este artigo introduz no debate a hipótese de que a desconsideração da perspectiva do federalismo, ou seja, a inobservância de princípios federativos pela governança do FNDCT, contribui para a fragilidade político-institucional de sua governança, e consequentemente, para a gestação da crise pela qual passa atualmente.

A sustentação dessa hipótese começa pelo exame dos esforços do Estado Brasileiro em adotar princípios federativos na Política Nacional de CT\&I, especificamente na gestão do

(11) Conforme reportagem do jornal Valor Econômico de 07/08/2017: "Ministro propõe mudar fundo de pesquisa tecnológica para driblar falta de recursos". 
FNDCT. Dessa análise, conclui-se que as iniciativas para considerar a perspectiva do federalismo na governança do FNDCT, como as exigências legais de percentuais mínimos dos recursos para regiões menos desenvolvidas economicamente, foram muito incipientes para garantir a diversidade da representação dos atores relevantes nas atividades de CT\&I.

Observa-se que - apesar repartição regional de recursos constituir um pré-requisito importante para o atendimento do princípio da autonomia dos estados menos desenvolvidos economicamente - não se pode afirmar que para o FNDCT a simples repartição regional de recursos satisfaça a esse princípio. Isso porque, diferentemente de outras áreas ou sistemas de políticas públicas, como Saúde, Educação e Assistência Social, em que há transferência de recursos entre entes e, simultaneamente, esforço de coordenação política e operacional conjunta - o FNDCT destina recursos diretamente a projetos ou instituições sem a participação dos entes subnacionais e sem coordenação do governo federal.

Sobre a inobservância do princípio da participação, constata-se que alterações legais a partir de 2007 introduziram instâncias decisórias (especialmente o Comitê de Coordenação Executiva, composto exclusivamente pelo MCTIC, CNPq e FINEP) que frustraram as expectativas de incluir o poder das representações setoriais e também a inclusão de uma agenda regional de $\mathrm{C} \& \mathrm{~T}$ com representações subnacionais.

Quanto às consequências da não observância dos princípios federativos, com base nas características do federalismo brasileiro, argumenta-se que os Poderes Executivo e Legislativo federais deixaram de exercer papéis conjuntos em decisões sobre a estabilidade de recursos e fontes de receitas do FNDCT. A maior evidência disso foi a aprovação de normativos prejudiciais à governança, "pró-crise", na medida em que autorizaram desvios das finalidades originárias estabelecidas pelas leis dos programas setoriais.

Sobre o futuro do FNDCT, confirmada a hipótese da fragilidade no arranjo políticoinstitucional de sua governança, conclui-se que a mera estabilidade de arrecadação e a exigência legal de repartição regional de recursos não serão suficientes para assegurar a estabilidade do apoio público às atividades de C\&T no País. Do ponto de vista do federalismo, esse desafio passará pela readequação da Política Nacional de CT\&I nos termos da EC n. 85/2015, que determina a organização do Sistema Nacional de Ciência, Tecnologia e Inovação (SNCTI) em regime de colaboração entre entes federativos. Certamente, será a primeira iniciativa político-institucional para a União incorporar efetivamente princípios federativos na governança da Política Nacional de CT\&I.

\section{Referências bibliográficas}

AMARAL FILHO, Jair do. Princípios do federalismo: contribuições metodológicas para sair do labirinto fiscalista. In: GUIMARÃES, Paulo Ferraz et al. (Org.). Um olhar territorial para $o$ desenvolvimento: Nordeste. Rio de Janeiro: Banco Nacional de Desenvolvimento Econômico e Social (BNDES), 2014. p. 304-327. 
ARRETCHE, Marta. Democracia, federalismo e centralização no Brasil. Rio de Janeiro: Editora Fiocruz, 2012.

ARRETCHE, Marta. Federalismo e igualdade territorial: uma contradição em termos. Dados, revista de Ciências Sociais, v. 53, n. 3, p. 587-620, 2010.

ARRETCHE, Marta. Quem taxa e quem gasta: a barganha federativa na federação brasilera. Revista Sociologia Política, n. 24, p. 69-85, jun. 2005.

ARRETCHE, Marta. Federalismo e políticas sociais no Brasil: problemas de coordenação e autonomia. São Paulo em Perspectiva, v. 18, n. 2, 2004.

ARRETCHE, Marta. Federalismo e Relações Intergovernamentais no Brasil: a reforma de programas sociais. Revista de Ciências Sociais, Rio de Janeiro, v. 45, n. 3, p. 431-458, 2002.

BRASIL. Relatório de Avaliação de Políticas Públicas: Fundos de Incentivo ao Desenvolvimento Científico e Tecnológico - Realidade e Crítica. Comissão de Ciência, Tecnologia, Inovação, Comunicação e Informática do Senado Federal. Brasília. Senado Federal. 2016. Disponível em: http://legis.senado.leg.br/comissoes/reuniao?6\&reuniao=5698\&codcol=1363. Acesso em: 8 jun. 2017.

BRASIL. Tribunal de Contas da União (TCU). Acórdão n. 500-8/2015. Plenário. TCU, n. 500$8,2015$.

BRASIL. Tribunal de Contas da União (TCU). Acórdão n. 1.232/2014. Plenário. TCU, n. $1.232,2014$.

BRASIL. Tribunal de Contas da União (TCU). Acórdão n. 3440/2013. Plenário. TCU, n. 3440, 2013.

BRASIL. Tribunal de Contas da União (TCU). Acórdão n. 2000/2012. Plenário. TCU, n. 2000, 2012 .

BRASIL. Tribunal de Contas da União (TCU) Acórdão n. 3081-53/2008 - Plenário. TCU, n. 3081-53, 2008.

BRASIL. Tribunal de Contas da União (TCU) Acórdão n. 686/2005 - Plenário. TCU, n. 686, 2005.

BRASIL. Ministério da Ciência e Tecnologia. Livro Branco: ciência, tecnologia e inovação. Brasília: Ministério da Ciência e Tecnologia, 2002.

BRITO CRUZ, Carlos Henrique de. Os Estados, a União e o apoio à pesquisa. Estadão.com.br, Opinião, 2 maio 2012. Disponível em: http://opiniao.estadao.com.br/noticias/geral,os-estadosa-uniao-e-o-apoio-a-pesquisa-imp-,867726. Acesso em: 2 jun. 2017.

BURDEAU, Georges. Traité de science politique. Paris: Ed. Librairie Générale de Droit et Jurisprudence, 1967. 
COSTA, Jean Mário Araújo; CUNHA, Maria Couto; ARAÚJO, Rosemeire Baraúna M. de. Federalismo Cooperativo Brasileiro: Implicações na gestão da educação municipal. Perspectivas em Políticas Públicas, Belo Horizonte. v. III, n. 5, p. 43-62, jan./jun. 2010.

DOURADO, Luiz Fernando. Sistema nacional de educação, federalismo e os obstáculos ao direito à educação básica. Educ. Soc., Campinas, v. 34, n. 124, p. 761-785, jul./set. 2013.

FIORI, José Luiz. O Federalismo diante do desafio da globalização. In: AFFONSO, R. B. A.; SILVA, P. L. B. (Org.). A Federação em perspectiva: ensaios selecionados. São Paulo: Fundap, 1995. p. 19-38.

FRANZESE, C.; ABRUCIO, F. L. A combinação entre federalismo e políticas públicas no Brasil pós-1988: os resultados nas áreas de saúde, assistência social e educação. In: REFLEXÕES para Ibero-América: a avaliação de programas sociais. Brasília: ENAP, 2009. p. 25-42.

LOPREATO, Francisco Luiz Cazeiro. O colapso das finanças estaduais e a crise da Federação. Fundação Editora da Unesp. IE. Unicamp, 2002.

LOPREATO, Francisco Luiz Cazeiro. Federalismo e finanças estaduais: algumas reflexões. Campinas: IE. Unicamp, set. 2000. (Texto para Discussão, n. 98).

LOPREATO, Francisco Luiz Cazeiro. Um novo caminho do federalismo no Brasil? Economia e Sociedade, Campinas, n. 9, p. 95-114, dez. 1997.

MARQUES, Fabrício. Financiamento em crise. Pesquisa da Fapesp, Edição n. 256, jun. 2017.

NASCIMENTO, Paulo A. Meyer M.; OLIVEIRA, João Maria de. Papel das ações transversais no FNDCT: redirecionamento, redistribuição, indução ou nenhuma das alternativas? Revista Brasileira de Inovação, Campinas, SP, v. 12, n. 1, p. 73-104, jan./jun. 2013.

OLIVEIRA, Fabrício Augusto de; BIASOTO JÚNIOR, Geraldo. A reforma tributária: removendo entraves para o crescimento, a inclusão social e o fortalecimento da federação. Campinas: IE. Unicamp, set. 2015. (Texto para Discussão, n. 260).

PACHECO, Carlos Américo. Políticas públicas, intereses y articulación política: cómo se gestaron las recientes reformas al sistema de ciencia y tecnología en Brasil. Santiago de Chile: Cepal, feb. 2005.

PACHECO, Carlos Américo. As reformas da política nacional de ciência, tecnologia e inovação no Brasil (1999-2002). In: CEPAL. Manual de políticas públicas. Santiago de Chile: dez. 2007.

PEREIRA JÚNIOR, Nilton; CAMPOS, Gastão Wagner de Sousa. O apoio institucional no Sistema Único de Saúde (SUS): os dilemas da integração interfederativa e da cogestão. Interface - Comunicação Saúde Educação, v. 18, n. I, p. 895-908, 2014. 
RIBEIRO, Guilherme Wagner; MACIEL, Ana Paula Magalhães. Federalismo, cooperação e políticas públicas: as experiências brasileiras. In: DIREITO e Administração Pública III. Editora Conpedi, 2014. p. 310-334. Disponível em: http://publicadireito.com.br/publicacao/ufpb/livro.php?gt=251. Acesso em: 3 jun. 2017.

RIZZOTTO, Maria Lucia Frizon; CAMPOS, Gastão Wagner de Sousa. O Banco Mundial e o Sistema Único de Saúde brasileiro no início do século XXI. Saúde Sociedade, São Paulo, v. 25, n. 2, p. 263-276, 2016.

SANTOS, Maria Helena de Castro. Governabilidade, governança e capacidade governativa. Brasília, DF, ENAP, 2001. (Texto para Discussão).

SANTOS, Maria Helena de Castro. Governabilidade, governança e democracia: criação de capacidade governativa e relações executivo-legislativo no Brasil Pós-Constituinte. Dados, Rio de Janeiro, v. 40, n. 3, 1997.

SOUZA, Celina. Federalismo, desenho constitucional e instituições federativas no Brasil pós1988. Revista de Sociologia Política, Curitiba, n. 24, p. 105-121, jun. 2005.

THÉRET, Bruno. La diversidad de los federalismos en América Latina: Argentina, Brasil y México. In. BIZBERG, Llán. Variedades del capitalismo en América Latina: los casos de México, Brasil, Argentina y Chile. El Colegio de México, Centro de Estudios Internacionales, 2015. 